TSIPI MARHAIM

Higher Studies of Israel

\title{
CHARACTERISTICS OF DEMOCRACY AND HUMANISM IN JANUSZ KORCZAK'S LEGACY
}

\begin{abstract}
AвSTRACT. Marhaim Tsipi, Characteristics of Democracy and Humanism in Janusz Korczak's Legacy [Charakterystyka demokracji i humanizmu w spuściznie Janusza Korczaka]. Studia Edukacyjne nr 46, 2017, Poznań 2017, pp. 425-438. Adam Mickiewicz University Press. ISSN 1233-6688. DOI: 10.14746/ SE.2017.46.27

In this article the author discusses the revolutionary and unique democratic-humanistic educational approach of Janusz Korczak (1878-1942), which emphasized the fundamental values of the human being concentrated on children and concerning their rights. The author presents democracy as a societal way of life, as practiced by Korczak, Wilczyńska and Falska. They administered their orphanages democratically, as expressed in Korczak's writings. Social and moral education is presented through a social lifestyle based on fundamental principles of democratic education in the spirit of Korczak. The article also examines the characteristics of democracy itself in the historical perspective and in relation to Korczak's democratic and humanistic approach. Humanism and democracy as regulators of social life can be greatly inspiring for teachers, educators and parents involved in the process of child education.
\end{abstract}

Key words: Korczak, democracy, humanism, education, educators

\section{Introduction}

A wave of revolutions, beginning in 1968 with the Prague Spring in Czechoslovakia, brought democracy to Eastern European countries. In the years 1980 to 1990 more southern and central European countries rejected Communism and embraced democracy. New democratic countries arose in Latin America, Southeast Asia, Africa and the Middle East and all over the world, especially in Arab countries. The Arab Spring swept through the Arab countries. It began in Tunisia in 2010, then in Algeria and Jordan and in Egypt in 2011, and was accompanied by demonstrations and civil wars. ${ }^{1}$

${ }^{1}$ O. Koenig, The Arab spring and democracy. A look at both comparative metrics, The Israel Democratic Institute, https://www.idi.org.il/articles/9678. 2013. 
We were able to observe that the movements of refugees led to demographic changes all over the world and raised dilemmas among democratic nations as to how to cope with multi-faceted cultures and mixed ethnic populations. This led to a move towards extremism in religious and nationalistic zealotry, plus the rejection of basic values and social commitments. ${ }^{2}$ Communication and politics determine the fundamental values of society. Technology has invaded our lives and made indirect interpersonal communication possible. The use of technological tools (cell phones, computers, telephones) has enabled the violation of individual rights, such as cyber bullying. These phenomena testify to the basic lack of understanding of the meaning of democracy in modern societies and distortion of the concept of free speech - which is one of its bases. There is a need for dialogue and moral, meaningful and value-based education for life in a democratic society.

Every day we witness violence, destructive wars and mass destruction, as a direct result of inhumane behavior and the disintegration of basic values; this requires a re-examination of universal values that protect human life and dignity and of shared life in a just society. The changing reality in the world raises fundamental humanistic questions about the essence of democracy. The complexity of the situation can be seen in education systems that expressed little tolerance or respect for others, thereby enabling rampant violence and inequality. Today, most public educational institutions are authoritative and operate according to uniform plans and outlines required by the Ministry of Education. Unfortunately, the emphasis placed on intellectual achievements and democratic-human-moral education is only theoretical. Therefore, it is important to devote attention to value based education. There is a need to educate children to live in a democratic state based on humanism, pluralism and democratic principles as well as to adopt a dynamic and flexible approach to global education.

Questions arise: What are the foundations of democracy, what are the essential elements for democratic education and how can we educate children to live in a democratic society?

I have examined various definitions of democracy since its early days in Athens in order to determine the characteristics of democracy. The liberal democratic approach, like Athenian democracy, is individual and supports personal freedoms, and concludes that human life is the foundation of democracy. Liberals emphasized individual rights, education, and personal development, and perceived education as a key to improving human nature.

2 D. Maskit, Practical experiencing during the process of educational training: model and data, Tel-Aviv 2016. 
John Dewey (1960) coined the concept of democratic education and argued that democracy is a way of life and must be expressed in the education system. ${ }^{3}$ An in-depth examination of the foundations of Korczak's democracy shows universal humanistic foundations. In Korczak's approach I found democratic-humanist ideas and ways to implement them, something that is sorely lacking in education today. Korczak's approach is an example for moral education, arouses inspiration and presents options for implementation. His character, his educational path and his approach, which are expressed in his writings, serve as a role model for learning.

The Jewish and Polish orphanages that Korczak administered were based on direct democracy as a way of life, with self-government and equality among children. These institutions were based on a democratic framework that included legislative, executive and judicial branches and were run through a parliament, a council and a court. These frameworks were innovative for their time and today they continue to serve as models for humanisticdemocratic approaches to education. Korczak considered education to be a philosophy of life that combines values and principles that complement each other, and he declared the need for children's rights. He required educators to constantly examine and adapt themselves to circumstances. His words raised questions, and the need to search for answers. His writings offer ideas and ways to adapt them. Incorporating his ideas into an educational system can provide the educational needs and environment for the present time. From my experience as principal of two schools that were run according to a humanistic democratic approach, Korczak's words strengthened our educational work and motivated us to change the shape of value-based educational frameworks and processes, which promoted the personal development of every child, together with a value-based education.

The fact that Korczak didn't write a clear theory but rather presented ideas based on observation, can help educators collect ideas and adapt them to their own environments and circumstances. Korczak's approach can strengthen the foundations of the humanistic-democratic approach in educators who apply it and can help them instill values in the existing educational system. His ideas can lead to a change in the school's structure, turning it into an environment that safeguards the needs of the children. Promotes educators' independence and the development of personal identity, helps them weave together their theory and the children's needs.

"I have a theory of my own; consciously or unconsciously it directs my activities, which stem from activity and experience." ${ }^{\prime 4}$

\footnotetext{
${ }^{3}$ J. Dewey, Democracy and Education, Jerusalem 1960.

${ }^{4}$ J. Korczak, Dat Ha Yeled (Religion of the Child), Tel Aviv 1978, p. 252.
} 
"One time I made an unwilling effort, and I worked out the theory for observation, planning and a program." ${ }^{5}$

Janusz Korczak wondered about the possibility of writing a coherent theory. He attempted to write his ideas on the basis "of the knowledge of others" and adapt these assumptions to his own views and possibilities. However, he regretted it and declared that he would not try to write again. Korczak did not write orderly systematic theory or any kind of a structured theory. ${ }^{6}$ In his opinion, the theory itself is not important because it consists of selective ideas that need to be chosen and changed by asking questions, searching and experiencing practical education. It can be stated that theory is temporary and changing and cannot be permanent and systematic. Every truth of today is a stage between stages. Korczak himself was against the presentation of a clear program that limits independent thought. He also contended that "a program is the distorter and killer of knowledge". ${ }^{7}$ The process of choosing the theories must be suited to the personality of the educator and to the needs of the children in the circumstances in which it takes place. He declared:

"The way I chose to move towards my goal is neither the shortest nor the easiest one, but for me it is the best one, because it is mine - my own."

But, will we make do with the idea that Korczak's writings are an eclectic reaction to the circumstances, without a connecting thread? We definitely cannot ignore the fact that Korczak was a significant educational guide and a figure from which to learn today and who can help educators identify their professional identity. ${ }^{9}$

\section{Theoretical and Practical Ideas in Korczak's Legacy}

Janusz Korczak (1878-1942) developed a revolutionary and unique educational approach which concentrated on the child, love for the child, his/her dignity and rights. His writings contained his approach to the child as a person with a special world who needs to be taught and whose abilities need to be fostered, and in addition, to educate them for life in society, with the active participation of the children.

His method for the administration of the orphanages was innovative and reflected democratic- humanistic values and principles.

${ }^{5}$ Ibidem, p. 253.

${ }^{6}$ M. Silverman, HaYeled Hu Adam (The Child is a Person), Tel Aviv 2012, p. 14.

7 J. Korczak, Dat HaYeled, p. 78.

8 J. Korczak, How to Love a Child, Ktavim 1, Regaim Hinuchiim, Zchut HaYeled LeKavod Collected Writings \#1 - How to Love a Child, Pedagogical Moments, The Child's Right to Respect, Tel Aviv 1996, p. 114.

9 M. Shner, Common sense and lack of knowledge inherent in the educational act or what Korczak learned from the ancient Greeks, Dapim 53, Tel Aviv 2012, p. 14-15. 
Korczak introduced the combination of conflicting values which complement each other as a solution to educational contradictions such as: freedom versus commitment, the individual versus society, listening versus clear regulations, reality versus imagination, dialogue and listening alongside order, limits, and organization. Korczak's theoretical ideas were written down, as he himself stated, through labor and torment.

In his writings he expresses interpersonal encounter, and a personal experience. He offers an approach, values and principles of action and frameworks which lead to implementation. The writing is succinct, associative, disjointed and the ideas are written as a collection of maxims. It is not edited in an orderly arrangement and with a concrete theory. ${ }^{10}$ Contrary to the order common to most educational theorists, his writing is not theoretical-linear-systematic, but rather relies on practice and is the result of a dialogical approach to the world and to education. His ideas are scattered throughout different books and include sentences and paragraphs that contain meaningful statements, sometimes with no connection between a paragraph and the following one.

His pedagogical writings are based on his own experiences and contain observation of the children's life, descriptions of children in the form of case studies and impressions of situations and events. His writings contain uncertainty, indecision and doubts, but belief in education. The ideas, which sometimes conflict with each other, express a state of affairs and promote thinking about educational activity and adapting it to existing conditions. According to him, action is the soul of accepted theory. The writing on educational subjects provided an explanation of practical educational experience. The practical work was an art of implementation that every educator needs to acquire by himself/herself. ${ }^{11}$ Korczak introduced theoretical ideas, suggestions based on his experience in education, an approach to the child based on democratic ideas and suggestions for the implementation of democratic education.

His narrative writing is usually rich in descriptions and metaphors and expresses a moral and value-based approach and serves as the basis for dialogues. His stories for children contain a social message and moral messages as a result of the influence of Polish modernism. ${ }^{12}$

His practical ideas described the way of life in the orphanages. The orphanages he founded were based on self-government and on equality between the children. Both orphanages had active democratic frameworks which included a legislative, executive and judicial authority.

\footnotetext{
${ }^{10}$ M. Silverman, HaYeled Hu Adam, p. 14.

11 T. Kurzweil, Korczak's place in educational thought, www.daat.ac.il/daat/kitveyet/niv/ korchak-2.ht m Niv Midrashiya, 1968, Winter, p. 2.

${ }^{12}$ M. Silverman, HaYeled Hu Adam, p. 302.
} 


\section{Humanistic and Democratic Foundations in Korczak's Educational Legacy}

In order to examine Korczak's democratic-humanistic approach, the article presents the changes that have taken place in the concept of democracy and the concept of humanism, the characteristics of democracy and humanism and which aspects of both democratic and humanistic ideas can be found in Korczak's writings.

Over the years democracies developed in various places in the world and many meanings were created for the term democracy. Leibowitz contends that there are many and even contradicting definitions which express different viewpoints and meanings. Each one of them expresses a specific viewpoint and different scales of values. ${ }^{13}$ Athenian democracy developed in the $6^{\text {th }}$ century B.C. The word democracy is derived from the Greek words demos - people and kratos - authority, i.e. rule of the people. Meaningful humanistic education led the Athenians in constructing their democratic path. The supporters of Athenian democracy considered the liberty of the individual a central principle which respects every person as a person with a divine spark. A free man had the right to express thoughts and to speak. The belief in citizens led to government by the people. It was characterized by the active participation of every free citizen in the People's Assembly (with the exclusion of women, strangers and slaves). The proponents of government by the people focus on the person and aspire to develop him by means of participation in decisions. In their opinion there is a need for mass, active participation by citizens in the political process and decision-making in order to fulfill individual rights and to encourage their participation from belief in the citizens' understanding and judgment. ${ }^{14}$ Citizens had the right to participate, speak, express a thought, offer proposals, express opinions and vote on decisions in the People's Assembly. The People's Assembly decided on general policy, appointment of positions, ongoing supervision, legislation and the imposing of taxes, while the people with the prominent positions who directly administered the current affairs of the state were elected. ${ }^{15}$ Athenian democracy was ruled by law, which was based on the hypothesis, that the law expresses the will of the people. Laws which were decided on with the citizens' participation could not be injurious to their freedom. All citizens were equal before the law, with no difference of status. However, the founders of Athenian democracy understood the need to change laws and adapt them to current circumstances. The principle of legal equality functioned in Athens and

${ }^{13}$ Y. Leibowitz, cited in: B. Neurberger, Modern Democracy: Intellectual Roots and Basic Concepts, Tel Aviv 1985. p. 103.

${ }^{14}$ R.A. Dahl (Ed.), Political Oppositions in Western Democracies, New Haven 1965, p. 399-400.

${ }^{15}$ B. Neurberger, Modern Democracy, p. 309-408. 
every Greek citizen (males only) had the right to apply to the court. ${ }^{16}$ Tolerance and compromise were part of democratic culture. The acceptance of variance between people requires acceptance of diverse ideas and multiple approaches and therefore, freedom of action cannot be restricted for strangers.

The characteristics of Athenian direct democracy were: freedom of the individual, trust in the citizens' understanding and judgment, acceptance of variance, government by the people, the rule of law and equality before the law. Tolerance and compromise were part of its democratic culture.

Aristotle (322-384 B.C.E.) related to the humanity in each person, respected his feelings and accepted his right to family and privacy. In his opinion there is only temporary and partial truth open to change, and therefore there is not one truth in democracy, but different truths. Not all the philosophers believed that democracy was the best system. Aristotle wrote that democracy was found in a group of bad systems, alongside tyranny and oligarchy. ${ }^{17} \mathrm{Pla}-$ to $(347$ - 427 B.C.E.), a Greek philosopher, student of Socrates and teacher of Aristotle, felt that democracy was the power of the poor people, which was linked to anarchy and demoralization. Plato defined that a stable social organization is one in which every individual functions according to his natural abilities in a way that is useful to society. The role of education, in his opinion, is indeed to discover abilities and train them for the benefit of society, but the question is how to do it. ${ }^{18}$ The answer is not through democracy, thus, Plato can't find a solution to the problem.

In Dewey's opinion (1960), Plato's philosophy is actually restricted to the idea of enslavement of individuality.He restricted people and their natural abilities in a static state because the purpose of life is permanent. Changes destroy education, and therefore education is dedicated to its preservation. ${ }^{19}$

\section{Liberal Democracy ${ }^{20}$}

In the $17^{\text {th }} 18^{\text {th }}$ and $19^{\text {th }}$ centuries modern democratic thought developed and was divided into two basic views, a liberal view and a radical view.

The liberal approach is individualistic. It means that personal freedom is part of the essence of being human and therefore it is a supreme value that must not be denied. Liberals emphasized individual rights, especially the right to self respect, education and personal development. In their opinion, education

${ }_{16}$ B. Shamai, Sefer HaAdam Veha Medina (The Book of the Person and the State), Tel Aviv 1974, p. 11.

17 Aristotle, The Politics II, Jerusalem 1974, p. 1.

18 B. Shamai, Sefer HaAdam VehaMedina, p. 11.

19 J. Dewey, Democracy and Education, Jerusalem 1960, p. 73.

20 J. Madison, The Federalist Papers, Ed. R. Farifield, No 20, New York 1966, p. 20. 
and learning, which recognize human dignity and liberty, can improve human nature. A democratic-legal-intelligent method can prevent human wickedness and injury to liberty, and it offers trust between free people with natural rights.

Liberal democracy is representative and recognizes a person's freedom to determine his/her way of life and the nature of the modern regime. ${ }^{21} \mathrm{Go}$ vernment by the people is based on the agreement of its representatives to act on behalf of the people and to defend their liberty through recognition of the people's supremacy. The representative method is not technical. The representatives in the Parliament have the important job of examining rivalries, judging problems and promoting compromise and tolerance between camps. The ruler is the emissary of the people, works on their behalf, and reports on his actions and receives support from a large part of the public.

The Radical and Contemporary approach to democracy and collectivist education ${ }^{22}$ emphasized the nation and the freedom of the community. The collective emphasis repressed the focus on the individual and his liberty. Democratic government is government on behalf of the whole and not necessarily to guarantee individual liberty. The nation is the government and so, the will of the majority determines the general will and can impose its will on local government. Jean-Jacques Rousseau represented this approach. ${ }^{23}$

Participatory democracy, or new Western theory, combines liberal and pluralistic foundations. It is perceived as a way of life, the goals of which are values, culture and trust in democratic citizens and leaders, who lead it through their personality and not only through institutions and laws. This is a moderate and tolerant worldview and way of behavior that professes free debate, agreement about differences of opinion and sometimes even compromise as an essential value in democracy. This is a life culture that is against violence and emphasizes a peaceful solution of problems ${ }^{24}$ Democracy today is indirect or representative. Most decisions are made by bodies elected to represent the public, such as parliaments, governments or elected presidents. A democratic regime governs and deals with problems through agreement of a majority of the people. This agreement is examined through elections. The role of democracy is to protect the minority from oppression by the majority. In this kind of democracy individual liberty is limited because of the need to respect the freedom of others. Government by the people does not guarantee individual liberty, but nevertheless it respects civil rights and supports freedom of opinion, religion, of the press, to protest and to strike, freedom of speech and movement. ${ }^{25}$

${ }^{21}$ G.S. Mill, On Liberty, Jerusalem 1979, p. 20.

22 B. Neurberger, Modern Democracy, p. 35.

$23 \mathrm{~J}$. . Rousseau, The Social Contract, Jerusalem 2006, p. 9.

${ }^{24}$ J. Lively, Democracy, New York 1977, p. 68.

25 B. Neurberger, Modern Democracy, p 67-68. 


\section{Democratic-Humanistic Ideas in Korczak's Legacy for Education in Society ${ }^{26}$}

According to Dewey, democracy is not just a form of government; it is also a way of life based on interpersonal relations. It contains a delicate balance between freedom and the rule of law, between individual rights and the needs of society. In order to preserve this balance, the citizen must be educated from a young age in the light of democratic values on which democratic life rests. ${ }^{27}$ Similar ideas were found in the writings of Janusz Korczak and John Dewey. We can also find the similarity between Dewey's and Korczak's ideas for educating children to live in a democratic society and also, practical frameworks. Dewey published his first book, Democracy and Education, in 1916. Korczak published his book in 1919, after serving as a medical officer at the front during World War I. However, there is no proof of a connection and mutual influence between the two.

Korczak's orphanage operated according to foundations of participatory democracy through democratic frameworks in which the children were full partners. The children learned about democracy through active partnership. According to Eisler, the active administration of the children's society would lead them to be involved and responsible, without the use of force. ${ }^{28}$

\section{Democratic Education in the Spirit of Korczak}

Korczak's orphanage was run on a basis of direct democracy as a way of life. The children were active partners in the administration of the home. Three separate authorities: a legislative authority, an executive authority and a judicial authority were activated in the house through democratic frameworks: a parliament, a council and a court.

The Parliament - the legislative authority, was composed of twenty-two elected representatives and Korczak was the chairman. They discussed matters of principle, enacted laws and amended them.

The Council - the executive and supervisory authority, which was elected on a yearly basis, was composed of ten children, headed by an educator. Its members proposed laws to the Parliament, supervised the order and cleanliness, saw to it that additional committees functioned properly and decided on the distribution of the postcards.

${ }^{26}$ Y. Dror, The Innovations of Janusz Korczak: An Educator whose Practice anteceded the Contemporary Educational Theories, [in:] Dor LeDor, Studies in the History of Jewish Education XXXIII, Tel Aviv 2008, p. 135-160.

27 J. Dewey, Democracy and Education, Jerusalem 1960, p. 72.

${ }^{28}$ R. Eisler, Tomorrow's Children: A Blueprint for Partnership Education for the 21st Century, Boulder Co 2000, p. 362. 
The Children's Court - the judicial authority, convened once a week to deal with the children's problems. The goal was to help and protect the weaker ones. It was composed of five judges. Stefa was the chairperson. Its verdicts were published every week. Korczak drew up the format of the court and wrote a law book that helped the children and the educators follow the regulations and laws of the orphanage. The book of laws contained suggestions of verdicts.

Korczak created a children's republic and educated for values and morals through the use of democratic frameworks and partnership with the children, giving them freedom alongside discipline by means of democratic-humanistic dialogue. The separation of the authorities is important and the clear separation between the authority of the children and the adults was an innovation and can contribute to meaningful democratic education today as well.

Humanistic education led the Athenians to construct democracy. The foundations of humanistic democracy led Korczak to construct the method of running the orphanages. There, one can find the humanistic foundations which guided the supporters of direct democracy in Athens, and the supporters of liberal democracy, who emphasized human rights and an individualistic democratic approach. They all share the expression in the Declaration of the Rights of Man and the Citizen in Paris in 1789: "Human beings are born and remain free and equal in rights". ${ }^{29}$

They were guided by their belief in humankind, recognition of their humanity and respect for their liberty. This human essence is inherent in Korczak's approach and actions, but he chose to focus on the dignity of the child as a person. The perception of individualism was characterized in Athenian democracy and Korczak's ideas.

- Personal talents - The supporters of Greek democracy saw a divine spark in the human being. ${ }^{30}$ Korczak used the term "spark" as an expression of his belief in humanity and encouraged looking for the spark that can light the way, promote a feeling of happiness and discernment of the truth.

"Everyone has a spark of his/her own that can light fires of happiness and truth."

- The principle of accepting variance among people was important in Athens and demanded acceptance and tolerance of multiple opinions and approaches.

Also, the liberal approach reveals a positive attitude towards diversity between people and opinions, which creates protection of minorities from the majority and encourages representatives in the Parliament to examine different opinions. Korczak wrote about the beauty of diversity as a stimulant to thought.

${ }^{29}$ B. Neurberger, Modern Democracy, p. 37.

${ }^{30}$ Ibidem.

${ }^{31}$ J. Korczak, How to Love a Child, p. 49; J. Korczak, "The Rules of Life", in Childhood of Respect, p. 336-337. (Hebrew) 
The colors of flowers and the shades of people's eyes differ.

And I allowed myself to see that only frivolous people want all people to be alike.

As opposed to Plato, he didn't think that abilities should be utilized for the good of society, but instead believed in natural abilities and contended that "there are no children without a talent, but the talent can be expressed through several means: the hand, the ear, the eye." 32

- The right to privacy - Aristotle emphasized the need to respect the person and his right to privacy. In Korczak's orphanage, each child had a personal cubbyhole for keeping his/her personal belongings, from recognition of the need for privacy.

- A temporary truth - In Aristotle's opinion there is only a temporary truth that is open to changes. Korczak also promoted a flexible and open diagnosis that required listening, examination and dialogue.

"Don't disparage the child. Adults discuss his fate; consult each other on how to behave with him, but who will ask for his opinion and agreement? Who will ask what the child has to say? After all, we can't manage without specialists - and the specialist is the child." 33

An individual is undoubtedly a part of society and knowledge of the rules and forms accepted in a society is essential for its proper functioning. Korczak was aware of the importance of both subjective and individualistic approaches, nevertheless, he believed in education for society through a democratic structure.

The foundations of democracy as it was expressed in Athens and by the liberals, a way of democratic life through active partnership in society and ruled by law can be found in Korczak's orphanages.

Similar to Greek democracy, there was direct democracy in the orphanages directed by Korczak, but in contrast to it, all the residents of the orphanages (children and adults as one) were present, participated and had the right to speak in the Council, to express ideas and even vote on the decisions, even though in the orphanage there

was also a ranking between pupils and citizens, members and residents.

- Freedom within the Limits of Laws - The Athenians believed in the rule of law and justice that expresses the will of the people. Laws enacted by the citizens cannot harm their freedom. The liberals believe in human wisdom and propose a convention between people.Also, in their opinion, a constitutional democratic system will prevent conflicts and will not harm human liberty.

Korczak proposed a code of regulations, familiar and known to all, and binding on all. He didn't believe in punishment and prizes, but rather parti-

${ }^{32}$ J. Korczak, Dat HaYeled, p. 102.

33 J. Korczak cited in: S. Sachs, Y. Kahana, Korczak: Memories and Contemplations, Tel Aviv 1989 , p. 75. 
cipation in thinking and understanding the meaning of the regulations. The individual needed to understand that the regulations were formulated in order to enable him to live in the society that was based on justice and security, and to develop in it. Korczak wrote a book of laws but the elected council had the right to appeal or to change laws with the agreement of the Parliament, in the way that the Greeks understood and what was agreed upon in Athens.

- The principle of equality before the law also operated in Korczak's orphanages and everyone in the orphanages was equal before the law. The Korczak court was meant for both children and adults equally, and they could take themselves to court when they erred. Korczak himself was tried several times because of mistakes that he made.

- The tolerance and compromise that were part of the democratic culture in Athens, and are one of the foundations of modern Western participatory democracy, suited the spirit of conduct in Korczak's orphanage. The book of laws that was used by the court encouraged the judges to listen, clarify, caution and to wait for improvement.

The basis of moral education is pedagogical forgiveness. This means waiting for the child to reach the insight on his own in order to improve his behavior. Improper behavior requires an examination of the reasons and provision of an opportunity to do better.

\section{Conclusion}

This quote summarizes Korczak's ideas as a connecting thread between the individual world and the worldof society: "Each child - is a large and extensive world. Two children - are three worlds; the world of each separate child and that of both of them together. Two children - are three worlds Four children - fifteen worlds ... and additionally, the world of all together." 34

Korczak, like the Athenians and the Liberals, placed the world of the individual, with its democratic and humanistic characteristics, at the center: respect for the child as a person, recognition of the children's rights, respect for different opinions, equality before the law, acceptance of variance between people and fostering of individual talents according to natural abilities.

Korczak the educator focused on the child-person, in an educational process and in fostering his/her involvement in society. His belief in the child's understanding led to a shared government of children and adults. By means of a democratic way of life in his orphanages, he educated his children to live in a democratic society, in the same way as Dewey did in his writings.

${ }^{34}$ J. Korczak, Dat HaYeled, p. 302. 
The characteristics of the democratic society he founded were: partnership and responsibility in the administration of the orphanage, all the children took part in the work in the home, provision of opportunities for personal expression (members' assembly, notice board, letters, newspaper and radio), and all the children had the opportunity to be elected as judges in the court or representatives in the parliament.

Janusz Korczak, together with Stefa Wilczynsla and Maria Falska, presented a model of education for democracy. The frameworks they developed and Korczak's writings can light the way of educators (educators, teachers and parents) in an educational process, and can provide them with ideas on how to educate children and students to be moral people and useful citizens in a democratic society in today's reality.

\section{BIBLIOGRAPHY}

Aristotle, The Politics II, Magnes Press, Jerusalem, Israel 1974.

Arnon Y., The Educational System of Janusz Korczak, Teachers Union House, Tel Aviv, Israel 1971.

Bandura A., Self Efficacy - the Exercise of Control, Freeman, New York 1997.

Ben Shamai M.H. (Ed.), Sefer Ha Adam Veha Medin (The Book of the Person and the State), Tel Aviv 1997. (Hebrew)

Dahl R.A. (Ed.), Political Oppositions in Western Democracies, Yale University, New Haven 1965.

Darom D., Aklim shel Tsmicha (A Climate of Growth), Sifriyat Hapoalim, Tel Aviv 1989. (Hebrew).

Dewey J., The School and Society, The University of Chicago, Chicago Ill. 1915.

Dewey J., Democracy and Education, Bialik Institute, Jerusalem 1960.

Dror Y., Educational Activities in Janusz Korczak's Home in Warsaw: a Historical Case Study and its Implications for Current Child and Youth Care Practice, Child and Youth Care Forum, 1998, 27(4).

Dror Y., The Innovations of Janusz Korczak: An Educator whose Practice anteceded the Contemporary Educational Theories, [in:] Dor LeDor, Studies in the History of Jewish Education XXXIII, Tel Aviv 2008. (Hebrew)

Eden S., The Impact of Korczak on Education in Israel, Jerusalem 1991.

Eden S., Henryk Goldszmit - Janusz Korczak, Achva, Jerusalem 2000. (Hebrew)

Efron S.E., Moral Education Between Hope and Hopelessness: The Legacy of Janusz Korczak, National-Louis University, Wheeling, IL, USA, published online 2015.

Eisler R., Tomorrow's Children: A Blueprint for Partnership Education for the 21st Century, Westview Press, Boulder Co 2000.

Haifa University, Iyunim Be-Morashto shel Janusz Korczak 1 (Studies in the Legacy of Janusz Korczak, 1), Haifa University Press, Haifa 1986. (Hebrew)

Haifa University, Iyunim Be-Morashto shel Janusz Korczak 2 (Studies in the Legacy of Janusz Korczak, 2), Hidekel, Tel Aviv 1989. (Hebrew)

Haifa University, Iyunim Be-Morashto shel Janusz Korczak 3 (Studies in the Legacy of Janusz Korczak, 3), Achva, Jerusalem 1991. (Hebrew). 
Haifa University, Iyunim Be-Morashto shel Janusz Korczak 4: Mekorot Hadashim meha-Ghetto (Studies in the Legacy of Janusz Korczak, 4: New Sources from the Ghetto), Achva, Jerusalem 1993. (Hebrew)

Haifa University, Iyunim Be-Morashto shel Janusz Korczak 5 (Studies in the Legacy of Janusz Korczak, 5), Achva, Jerusalem 1995. (Hebrew)

Haifa University, Iyunim Be-Morashto shel Janusz Korczak 6 (Studies in the Legacy of Janusz Korczak, 6), Achva, Jerusalem 1996. (Hebrew)

Hassan, To Be a Person who loves People, In the monthly magazine Kesher Ayin [Eye Contact], 2016.

Koenig O., The Arab spring and democracy. A look at both comparative metrics, The Israel Democratic Institute, https:/ /www.idi.org.il/articles/9678. 2013.

Korczak J., Honor of childhood, Shamgar, Tel Aviv 1976.

Korczak J., Dat Ha Yeled (Religion of the Child), Shamgar, Tel Aviv 1978. (Hebrew)

Korczak J. cited in: S. Sachs, Y. Kahana, Korczak: Memories and Contemplations, Papyrus, Tel Aviv 1989.

Korczak J., How to Love a Child, Ktavim 1, Regaim Hinuchiim, Zchut HaYeled LeKavod Collected Writings \#1 - How to Love a Child, Pedagogical Moments, The Child's Right to Respect, Hidekel, Tel Aviv 1996. (Hebrew)

Korczak J., "The Rules of Life", in Childhood of Respect,

Kurzweil T., Korczak's place in educational thought, www.daat.ac.il/daat/kitveyet/niv/korchak-2.ht m Niv Midrashiya, 1968, Winter.

Leibowitz Y., cited in: B. Neurberger, Modern Democracy: Intellectual Roots and Basic Concepts, Tel Aviv 1985.

Lively J., Democracy, Putnam, New York 1977.

Madison, The Federalist Papers, Ed. R. Farifield, No 20, Doubleday, New York 1966.

Maskit D., Practical experiencing during the process of educational training: model and data, Mofet, Tel-Aviv 2016.

Mil G.S., On the freedom, Magnes, Jeruzalem 1979.

Neurberger B., Modern Democracy: Intellectual Roots and Basic Concepts, Tel Aviv 1985.

Ruso J.J., The social contract, Magnes, Jeruzalem 2006.

Sachs S., Kahana Y., Korczak: Zichronot VeHagigim (Korczak: Memories and Contemplations), Tel Aviv 1989. (Hebrew)

Shamai B., Sefer HaAdam Veha Medina (The Book of the Person and the State), Neuman, Tel Aviv 1974. (Hebrew)

Shener M., Common sense and lack of knowledge inherent in the educational act or what Korczak learned from the ancient Greeks, Dapim 53, Mofet, Tel Aviv 2012.

Silverman M., HaYeled Hu Adam (The Child is a Person), Mofet, Tel Aviv 2012. (Hebrew) 